\title{
NPPA Gene Product
}

National Cancer Institute

\section{Source}

National Cancer Institute. NPPA Gene Product. NCI Thesaurus. Code C139909.

A protein encoded by the NPPA gene. 